\title{
Insulin in human milk: postpartum changes and effect of gestational age
}

\author{
N Shehadeh, E Khaesh-Goldberg, R Shamir, R Perlman, P Sujov, A Tamir, I R Makhoul
}

See end of article for authors' affiliations

.....................

Correspondence to: Dr Makhoul, Department of Neonatology, Meyer Children's Hospital, Rambam Medical Center, Bat-Galim, Haifa, 31096 Israel; makhoul@ rambam.health.gov.il

Accepted 27 August 2002

\begin{abstract}
Objective: To determine if human milk insulin (HMI) concentrations are affected by gestational age and postnatal age.

Design and setting: An observational study carried out in a level III neonatal intensive care unit. Insulin concentrations were determined in human milk of 90 parturient mothers who delivered between 30 and 41 weeks gestation. Samples were collected on days 3 and 10 after delivery.

Results: $\mathrm{HMI}$ concentrations for mothers of preterm infants were not significantly different from those of full term infants, on either day 3 or 10 post partum. When results for all 90 mothers were pooled, regardless of gestational age, $\mathrm{HMI}$ concentration fell significantly from day 3 to day 10 (50.1 (34.6) $\checkmark 41.1(28.5) \mathrm{uU} / \mathrm{ml} ; \mathrm{p}=0.01$; mean (SD)). However, this decrease was only significant for mothers delivering at term (37-41 weeks).

Conclusions: HMl concentrations were not influenced by gestational age at delivery. They decreased post partum, mainly in mothers of term infants. The postnatal changes in $\mathrm{HMl}$ concentrations and the effects of oral insulin on the immature intestinal mucosa warrant further investigation.
\end{abstract}

$\mathrm{B}$ reast feeding supports gut maturation by providing growth hormones such as insulin. Insulin can interact with intestinal mucosa whether given orally or systemically, because its receptors are found on both the apical and basolateral enterocyte membranes. ${ }^{1}$ The positive effects of oral insulin on gut maturation and mucosal enzyme expression have so far been shown in suckling mice, ${ }^{2}$ suckling rats, ${ }^{3}$ and newborn piglets, pigs, and calves. ${ }^{4-6}$

In a recent study, we showed that the insulin concentration of human milk after full term delivery $(60.2(41.1) \mathrm{mU} / \mathrm{ml})$ is significantly higher than that of cow's milk (16.3 (6.0) $\mathrm{mU} / \mathrm{ml}$ ), and that insulin is barely detectable in infant formulas. ${ }^{7}$

It has been suggested that insulin content has a dominant role in the overall effect of breast milk on gut maturation, as it has been shown in lactating animals that milk borne insulin is active, and that immature enterocytes have increased responsiveness to insulin. ${ }^{8}$ These growth and maturation promoting effects of oral insulin on the gastrointestinal tract of the neonate, in particular the premature neonate, may be of great importance. It is not known, however, if preterm infants are exposed to the same concentration of human milk insulin (HMI) as full term infants, and whether there are changes in HMI concentration over time.

Our goal was to determine whether HMI levels are affected by gestational age (GA) at delivery, and to examine the postpartum changes in HMI concentrations.

\section{METHODS}

This study was approved by the institutional Helsinki Committee, and written informed consent was obtained from participating mothers.

\section{Study population}

Human milk samples were collected from nursing nondiabetic healthy mothers on days 3 and 10 after delivery of preterm and term infants (GA range, 30-41 weeks). Ninety parturient women who participated in the study were divided into four groups according to GA at delivery: group 1, 30-32 weeks; group 2, 33-34 weeks; group 3, 35-36 weeks; group 4, 37-41 weeks. Table 1 shows the characteristics of the participants.

\section{Milk samples and insulin measurements}

Milk was expressed using a breast milk pump (Medela, Medical Technology, Baar, Switzerland). Insulin level was measured as previously described. ${ }^{4}$ All samples were stored in polypropylene tubes at $-20^{\circ} \mathrm{C}$. Fat free supernatant was obtained by diluting the milk samples with phosphate buffered saline (10 $\mathrm{mM} \mathrm{KH} \mathrm{PO}_{4}, 0.15 \mathrm{M} \mathrm{NaCl}, \mathrm{pH} 7.4$ ) and centrifugation at $100000 \mathrm{~g}$ for $60 \mathrm{~min}$. Clear supernatant was aspirated and stored at $-20^{\circ} \mathrm{C}$. Insulin concentrations were determined by radioimmunoassay with a commercial kit (DiaSorin, Saluggia, Italy), using human insulin as standard. The coefficient of variation in the same sample with this method was $6.6 \%$ ( $\mathrm{n}=10$, mean $24.1(1.6) \mu \mathrm{U} / \mathrm{ml}$ ). We did not measure insulin content in the fat fraction.

\section{Statistical analysis}

The data were not normally distributed and therefore comparisons of HMI concentration between the four groups on days 3 and 10 were performed using the non-parametric Kruskal-Wallis test. A paired Wilcoxon test was used to compare HMI concentrations on days 3 and 10 in each study group. $\chi^{2}$ test was used to compare categorical variables such as mode of delivery. Spearman's correlation coefficients were calculated to examine the relation between quantitative variables-for example, HMI concentration on days 3 and 10 and maternal body mass index (BMI). $p<0.05$ was considered significant.

\section{RESULTS}

Table 1 shows that the four study groups were not significantly different with respect to maternal age, ethnic origin, singleton births, weight gain during pregnancy, and maternal BMI. However, group 4 differed from the other three groups in that it included significantly more vaginal deliveries $(p<0.05)$.

Table 2 shows HMI concentrations on days 3 and 10 in the four study groups. An intergroup comparison on day 3 shows

Abbreviations: $\mathrm{HMI}$, human milk insulin; $\mathrm{GA}$, gestational age; $\mathrm{BMI}$, body mass index 
Table 1 Characteristics of the 90 parturient mothers participating in the study

\begin{tabular}{lllllll}
\hline Group & No & $\begin{array}{l}\text { Maternal age } \\
\text { (years) }\end{array}$ & $\begin{array}{l}\text { Vaginal } \\
\text { delivery (\%) }\end{array}$ & $\begin{array}{l}\text { Jewish origin } \\
(\%)\end{array}$ & $\begin{array}{l}\text { Singleton birth } \\
(\%)\end{array}$ & $\begin{array}{l}\text { Maternal weight } \\
\text { gain in pregnancy } \\
(\mathrm{kg})\end{array}$ \\
\hline Group 1 (30-32 weeks) & 20 & $27.9(3.0)$ & 30.0 & 75.0 & 55.0 & $12.5(7.0)$ \\
Group 2 (33-34 weeks) & 23 & $28.7(3.4)$ & 34.8 & 47.8 & 65.2 & $14.5(6.9)$ \\
Group 3 (35-36 weeks) & 23 & $28.8(4.5)$ & 34.8 & 52.2 & 69.6 & $12.1(6.4)$ \\
Group 4 (37-41 weeks) & 24 & $28.9(3.4)$ & $66.7^{*}$ & 50.0 & 87.5 & $14.0(5.9)$ \\
\hline
\end{tabular}

Unless otherwise indicated, values are mean (SD).

* Significantly different from the other three groups $(p<0.05)$.

BMl, Body mass index $=$ weight $(\mathrm{kg}) /(\text { height }(\mathrm{m}))^{2}$.

no significant differences. Similarly, no differences in HMI concentrations between the groups were found on day 10 .

When the results for all 90 mothers were pooled (table 2), HMI concentration was significantly higher on day 3 (mean (SD), 50.1 (34.6); median, $41.0 \mu \mathrm{U} / \mathrm{ml}$ ) than on day 10 (mean (SD), 41.1 (28.5); median, $34.0 \mu \mathrm{U} / \mathrm{ml})(\mathrm{p}=0.01)$. However, the decline in HMI concentration from day 3 to day 10 occurred in only $59 \%$ of the 90 mothers, and HMI concentration actually increased in $41 \%$ of the mothers (an increase of more than $5 \mu \mathrm{U} / \mathrm{ml}$ in $26 \%$ of mothers and less than $5 \mu \mathrm{U} / \mathrm{ml}$ in $15 \%)$.

HMI concentration was lower on day 10 than on day 3 in all the study groups (table 2). However, this decrease was not significant in groups 1,2 , and 3 , but was significant in group 4 $(\mathrm{p}=0.004)$.

When the results for all 90 mothers were pooled, HMI concentration was not significantly influenced by GA at delivery, maternal age, ethnic origin, mode of delivery, number of newborns delivered (singleton or multiple), weight gain during pregnancy, or BMI, on day 3 or day 10 post partum.

\section{DISCUSSION}

The main finding of our study is that HMI concentrations are not influenced by GA, and premature infants are exposed to similar concentrations of insulin in human milk to full term infants.

Insulin in mature milk of humans and pigs appears to influence small intestinal growth and development. ${ }^{4}$ Ileal lactase activity in newborn piglets is increased when porcine insulin is added to feeds, ${ }^{4}$ and milk borne insulin induces pancreatic amylase development in rats at the onset of weaning. ${ }^{9}$ Moreover, oral insulin plays an important role in the maturation of regulatory mechanisms governing the intestinal passage of macromolecules, as evidenced by the suppression of immunoglobulin $\mathrm{G}$ absorption in adrenalectomised suckling rats that received oral insulin supplementation. ${ }^{10}$

The above data suggest that oral insulin is important for intestinal maturation in the developing gastrointestinal tract. The intestinal mucosa of premature infants is underdeveloped and often cannot properly handle enteral feeding; indeed, early enteral feeding of premature infants can cause intestinal and systemic complications, such as maldigestion, ${ }^{11}{ }^{12}$ malabsorption, ${ }^{12}$ diarrhoea, and necrotising enterocolitis. ${ }^{13}$ We did not include premature infants of less than 30 weeks gestation in our study. However, this would be particularly relevant in future studies as smaller babies are most susceptible to gastrointestinal disease.

As insulin is important for gut maturation, we were interested to explore changes in HMI concentrations post partum. Our pooled data indicate that the mean HMI concentration on day 3 was significantly higher than on day 10. The difference increased as GA increased (groups 3 and 4 versus groups 1 and 2), but the differences were not significant and did not correlate with GA $(p=0.1)$. However, a significant decrease in HMI concentration from day 3 to day 10 was observed in the group of full term infants (group 4). This group contained significantly more infants delivered spontaneously. However, when the results for all 90 parturient mothers were pooled, there was no significant effect of mode of delivery on HMI concentration. In addition, postpartum HMI concentration, on both day 3 and day 10, was not influenced by maternal age, ethnic origin, mode of delivery, weight gain in pregnancy, or by maternal BMI.

There is great variability in serum insulin levels in parturient mothers, ${ }^{14}$ which may be caused by factors such as insulin

\begin{tabular}{|c|c|c|c|c|c|}
\hline Group & No & & Day 3 & Day 10 & $\mathrm{p}$ Value \\
\hline Group 1 (30-32 weeks) & 20 & $\begin{array}{l}\text { Mean } \\
\text { Median } \\
\text { Range }\end{array}$ & $\begin{array}{l}50.6(29.9) \\
43.0 \\
19-140\end{array}$ & $\begin{array}{l}49.2(33.4) \\
44.0 \\
16-135\end{array}$ & NS \\
\hline Group 2 (33-34 weeks) & 23 & $\begin{array}{l}\text { Mean } \\
\text { Median } \\
\text { Range }\end{array}$ & $\begin{array}{l}39.9(35.0) \\
33.9 \\
7-179\end{array}$ & $\begin{array}{l}35.3(20.4) \\
34.0 \\
13-93\end{array}$ & NS \\
\hline Group 3 (35-36 weeks) & 23 & $\begin{array}{l}\text { Mean } \\
\text { Median } \\
\text { Range }\end{array}$ & $\begin{array}{l}51.0(34.9) \\
41.0 \\
12-140\end{array}$ & $\begin{array}{l}40.8(23.1) \\
36.0 \\
16-122\end{array}$ & NS \\
\hline Group 4 (37-41 weeks) & 24 & $\begin{array}{l}\text { Mean } \\
\text { Median } \\
\text { Range }\end{array}$ & $\begin{array}{l}58.7(37.0) \\
51.0 \\
16-170\end{array}$ & $\begin{array}{l}40.2(34.8) \\
29.0 \\
12-183\end{array}$ & 0.004 \\
\hline All groups (30-41 weeks) & 90 & $\begin{array}{l}\text { Mean } \\
\text { Median } \\
\text { Range }\end{array}$ & $\begin{array}{l}50.1(34.6) \\
41.0 \\
7-179\end{array}$ & $\begin{array}{l}41.1(28.5) \\
34.0 \\
12-183\end{array}$ & 0.01 \\
\hline
\end{tabular}


resistance, fed or fasting state, and levels of counterregulatory hormones. Such maternal variability may account for the large variation in insulin concentrations observed in human milk. This may explain the different patterns of change in postpartum HMI concentration that we observed: although there was an overall decrease in HMI concentration from day 3 to day 10, the decrease was observed in only 59\% of the samples, and in $41 \%$ of the samples the HMI concentration actually increased. Furthermore, the postpartum fall in HMI concentration was more notable in full term neonates than in premature neonates, albeit not significantly so. We speculate that, unlike the full term neonate, the premature neonate may still need insulin after birth as the main growth hormone.

The overall fall in HMI levels after the third postpartum day is consistent with previous observations. ${ }^{7}{ }^{15}$ Slebodzinski et a ${ }^{15}$ showed a direct relation between the content of insulin in human milk and the actual concentrations of this hormone in maternal blood; insulin content tended to be higher in colostrum, and fell gradually during the first postpartum weeks.

The significant difference in insulin concentrations found in full term and preterm human milk, and the beneficial effects of oral insulin on gut maturation should be pondered for their possible clinical implications. Infant formulas used to feed premature infants do not contain this important hormone, ${ }^{7}$ and we believe that the addition of human insulin to infant formulas in a concentration similar to that present in human milk may be advantageous, especially for premature infants. Studies are warranted to evaluate the potential effects of oral administration of human insulin to premature infants receiving formulas based on cow's milk.

Our suggestion conforms with the statement of Oski ${ }^{16}$ : "Just because children are not breast-fed doesn't mean they shouldn't have every possible nutritional advantage. That's why formulas should match as closely as possible the composition of human breast milk".

\section{ACKNOWLEDGEMENTS}

We thank Professor Moshe Berant, Professor Avraham Benderly, and Lea Solovachik for helpful assistance and advice. For E K-D, this study served as partial fulfilment of the requirements for Residency in Pediatrics by the Israeli Medical Council.

\section{Authors' affiliations}

N Shehadeh, E Khaesh-Goldberg, R Shamir, R Perlman, P Sujov, A Tamir, I R Makhoul, Juvenile Diabetes Unit, and Departments of

Pediatrics, Gastroenterology and Nutrition, and Neonatology, Rambam Medical Center and Bruce Rappaport Faculty of Medicine,

Technion-Israel Institute of Technology, Haifa, Israel

\section{REFERENCES}

1 Buts JP, De Keyser N, Marandi S, et al. Expression of insulin receptors and of $60-\mathrm{kDa}$ receptor substrate in rat mature and immature enterocytes. Am J Physiol 1997:273:G217-26.

2 Arsenault $\mathbf{P}$, Menard D. Insulin influences the maturation and proliferation of suckling mouse intestinal mucosa in serum free organ culture. Biol Neonate 1984;46:229-6.

3 Marandi S, De Keyser N, Saliez A, et al. Insulin signal transduction in rat small intestine: role of MAP kinases in expression of mucosal hydrolases. Am J Physiol 2001;280:G229-40

4 Shulman RJ. Oral insulin increases small intestinal mass and disaccharidase activity in the newborn miniature pig. Pediatr Res 1990;28:171-5.

5 Asplund JM, Grummer RH, Philip PH. Absorption of colostral gamma-globulins and insulin by the newborn pig. J Anim Sci 1962:21:412-13.

6 Pierce AE, Risdall PC, Shaw B. Absorption of orally administered insulin by the newly born calf. J Physiol (Lond) 1964:171:203-5.

7 Shehadeh N, Gelerntner L, Blazer S, et al. The importance of insulin content in infant diet: suggestion for a new infant formula. Acta Paediatr $2001 ; 90: 93-5$

8 Buts JP, De Keyser N, Sokal EM, et al. Oral insulin is biologically active on rat immature enterocytes. J Pediatr Gastroenterol Nutr 1997;25:230-2.

9 Kinouchi T, Koizumi K, Kuwata T, et al. Milk-borne insulin with trypsin inhibitor in milk induces pancreatic amylase development at the onset of weaning in rats. J Pediatr Gastroenterol Nutr 2000;30:515-21.

10 Harada E, Syuto B. Precocious cessation of intestinal macromolecular transmission and sucrase development induced by insulin in adrenalectomized suckling rats. Comp Biochem Physiol $A$ 1991;99:327-31

11 Kein CL, Heitlinger LA, Li BU, et al. Digestion, absorption and fermentation of carbohydrates. Semin Perinatol 1989:13:78-87.

$12 \mathrm{Neu} J$, Koldovsky O. Nutrient absorption in the preterm neonate. Clin Perinatol 1996;23:229-43.

13 Amoury RAE. Necrotizing enterocolitis. In: Ashcraft KW, Holler TM eds. Necrotizing enterocolitis in pediatric surgery. Philadelphia: WB Saunders, 1993:341.

14 Wang HS, Lee JD, Soong YK. Effects of labor on serum levels of insulin and insulin-like growth factor-binding proteins at the time of delivery. Acta Obstet Gynecol Scand 1995;74:186-93

15 Slebodzinski AB, Nowak J, Gawecka H, et al. Thyroid hormones and insulin in milk: a comparative study. Endocrinol Exp 1986;20:247-5.

16 Oski FA. What we eat may determine who we can be. Nutrition 1997; 13:220-1. 